\title{
Effectiveness of Using Football Basics in Physical Education and Organizing Arts and Cultural Events for Promoting Harmonious Development of Orphan Children
}

\section{Elvir Munirovich Akhmetshin}

Kazan Federal University, Elabuga Institute, Russia,akhmetshinelvir@yahoo.com

\author{
Almaz Faridovich Miftakhov \\ Kazan Federal University, Elabuga Institute, Russia, miftahovalmaz83@mail.ru \\ Dilyara Akhnafovna Murtazina \\ Kazan National Research Technological University, Russia, sha-dilyara@yandex.ru

\section{Rodion Pavlovich Sofronov} \\ North-Eastern Federal University named after M.K. Ammosov, vorovul@yandex.ru

\section{Natalia Mikhailovna Solovieva} \\ North-Eastern Federal University named after M.K. Ammosov, kmpf_snm@mail.ru

\section{Vyacheslav Anatolyevich Blinov} \\ Siberian State University of Physical Education and Sport, Russia, timfh@mail.ru
}

Orphans and children left without parental care remain a pressing challenge for many countries. This paper deals with the topical subject which needs thorough consideration: peculiarities of psychological development of orphans and children left without parental care and training orphanage inmates for social interaction. The 7-months study was conducted on 15-16-year-old orphans at Elabuga, the Republic of Tatarstan, and Russian Federation. Data were collected with a designed questionnaire based on the Temperament and Character Inventory for personality traits devised by Robert Cloninger. 20 apparently healthy orphans and children left without parental care were selected using simple random sampling technique and allocated into two groups. Within the experiment the two groups of orphan children had separate Physical education classes in subgroups.

Keywords: orphan children, adolescents, football, training process, extracurricular activities, academic performance 


\section{INTRODUCTION}

UNICEF and global partners define an orphan as a child under 18 years of age who has lost one or both parents to any cause of death (UNICEF, 2017). There are nearly 168 million orphans globally in 2018 (Worldwide Children's Statistics, 2018). Evidence clearly shows that the vast majority of orphans are living with a surviving parent, grandparent, or other family member. $95 \%$ of all orphans are over the age of five. This figure represents not only children who have lost both parents, but also those who have lost a father but have a surviving mother or have lost their mother but have a surviving father. Of the nearly 168 million children classified as orphans, 15.1 million have lost both parent (UNICEF, 2017).

According to Russia's state statistics, nearly 150,000 orphans are provided care in residential care establishments; however the number of children who need social protection is about 500,000 (Children's homes statistics, 2017). Currently there are over 400 children's homes, nearly 750 orphanages and over 200 boarding homes in Russia. According to federal statistical observation 6,500 children were adopted in 2017; 53,700 orphans were either placed in formal fostering or under guardianship, patronage or trusteeship. At present federal executive authorities are involved in elaborating the Concept of the development of the system for the prevention of juvenile delinquency until 2020 (Children's homes statistics, 2017).

In the last decade there has been a significant growth in the number of orphans and vulnerable children in various parts of the world (Pillay, 2018). Development policymakers and child-care service providers are committed to improving the educational opportunities of orphans worldwide. The relationship between orphanhood and education outcomes is not well understood. Recent studies show that there exist the relationship between psychosocial well-being and cognitive development of orphans and abandoned children relative to non-orphan children in low and middle income countries (Escueta et al., 2014). Early childhood education is the main vehicle to address the concerns of orphan and vulnerable children in order for them to develop skills and human capital as future adults (Pillay, 2018).

Some researchers suggest that orphanhood is clearly an important dimension of child vulnerability, though other factors in some cases have a stronger quantitative association with child development. Contrasting evidence suggests that gender and region of residence are also important predictors of poor schooling outcomes of orphan children; urban orphans appear to be more vulnerable than their urban peers (Campbell et al., 2010). Findings also show that the poorest students, and girls especially, experience disparity, therefore they should be given more opportunities to attain an education and to reach their potential, contributing to family and national health and wealth (Lingenfelter et al., 2017; Naidu et al., 2008; Jeffery et al., 2015).

The general physical and psychological development of children left without parental care differs from the development of their peers raised in families (Asif, 2017).They demonstrate a psychological development delay and a number of specific problems: a lower level of intellectual development, poorer imagination and emotional sphere; they are slower to learn self-regulation and correct behavior (Crockenberg et al., 2008), 
(Majanga et al., 2015). Consequently, it has a serious negative influence on the development of a growing personality (Dubrovina et al., 1995).

Some teenagers without parental care are unable to cope with elementary household activities and get lost in a simple difficulty, i.e. they can't survive on their own without support (Kiambi and Mugambi, 2017). Thus a reasonable question arises, why these children are incapable of getting adapted to the life like many of those who were raised together with them (Braginskiy, 2005). Orphans have difficulty in adapting to everyday life (Better Care Network Secretariat, 2009). In this regard, it is necessary to determine which teaching methods and means are to be used to help children left without parental care overcome their psychological complexes and organize their lives on their own (Nyberg et al., 2012). Education, and physical education as well, is the major factor influencing the formation of a person's abilities and it can work wonders (Zhou, 2012).

As the number of orphan children is growing, it is becoming more difficult for their communities and guardianship authorities to address all their needs (Chiroma, 2016). There is an urgent need to develop culturally appropriate psychometric tools and measures for the support of orphans and children left without parental care. The educational process and care given to them should be organized so that they not only meet physical needs but also include psychosocial support, allowing children to cope with orphan hood life and future adult life with ease (Thwala, 2013; Kayombo et al., 2005).

Orphan hood caused by parental death, disrupted bonds during childhood affect the life of children in a negative way including the risk of being low in self-esteem (Erango and Ayka, 2015). There is a diversity and complexity of reasons that determine the mothers' role in the education of their children (Anyikwa and Obidike, 2012). Orphan children are more subject to internalizing problems: pessimism, depressive and anxiety disorders, sense of failure (Makame et al., 2002).Adverse childhood events have a negative effect on latter life cognitive performance and are correlated with intelligence, academic achievement and other developmental outcomes in later life of orphans (Purohit and Pradhan, 2017). Studies have shown that children with poverty and early life stress have reduced executive function, while physical activities are an important factor for both physical and mental health, making friendship, and for success in school (Alloway and Alloway, 2010). It also predicts school readiness, later academic performance and adapting to independent adult life (Borella et al., 2010).

The adolescence period is a period of reorganising the teenager's self-image. In a recent analysis it is pointed out that the teenagers' constant participation at physical education lessons and the presence of physical exercises in their life increase their self-esteem and improve their self-image. Mental health and physical fitness play a determinant role in the formation of a positive self-image and affect cognitive development (Lupu and Petrescu, 2012; Sabau et al., 2014).

In the system of Russian education physical education is aimed at contributing to the allround and harmonious development of an individual, preserving and improving children's health, and training members of society for future professional activities (Rayzikh et al., 2017). 
The objective of the study was to evaluate the effect of introducing a 7-month Football Basics program into Physical education, arranging personal growth trainings and attending arts and cultural events for promoting the spiritual, moral and mental development of orphans and children left without parental care.

\section{METHOD}

\section{Participants and sampling technique}

There are 654,000 orphans in Russia today, $84 \%$ of them are qualified as orphans with one or both surviving parents; $78 \%$ are provided with family-based care; $19 \%$ are cared for in residential care establishments: children's homes, orphanages, boarding homes, and schools for children without parental care; $3 \%$ are either cared for in other types of public institutions or unregistered by guardianship authorities (Figure 1).
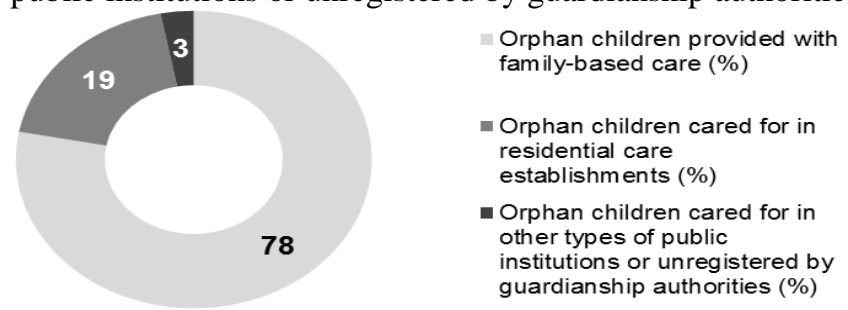

Figure 1

Percentage of Orphan Children in Russia (according to Russia's state statistics, 01.01.2018)

20 orphans and children left without parental care were chosen for the study based on the inclusion and exclusion criteria. Participants were eligible for inclusion into the experiment according to the following criteria: a) an orphan or a child left without parental care, b) aged between 15 and 16 years, c) boys and girls, d) without any chronic disease, physical, or mentally handicap. The study was conducted between October 2017 and April 2018 in an orphanage in Elabuga, Republic of Tatarstan, and Russian Federation. Participants were divided into two groups of 10: a) experimental group, which underwent Football Basics Program, Personal Growth Trainings and attended arts and cultural events for 7 months; b) control group, which underwent routine activity.

\section{Data collection tools}

Before and after the experiment orphan children were asked to fill in the questionnaire on seven dimensions of personality traits and three characters, which covered the domains of mood and emotional state, state of health, physical activity, education, relationships with other children and adults, safety.

The questionnaire was conducted by 3 teachers and took one day. It was organized in the educational institution attended by inmates of the orphanage (Secondary General School \#2, Elabuga). Microsoft Excel spreadsheet was used for systematizing and analyzing the questionnaire results and mathematical processing of statistical data. Consent for private data processing was confirmed in writing by all participants. None of the children refused to take part in the questionnaire survey. Irrelevant responses were not identified in the questionnaire. The statistical error was 5\%. 


\section{Research design}

The questionnaire survey used in the experiment is based on the Temperament and Character Inventory for personality traits devised by Robert Cloninger (1994). The original version was adapted and translated into Russian by S.N. Yenikolopov and A.G. Yefremov in 2001 and held 125 statements (Yenikolopov and Yefremov, 2001); by O.M. Razumnikova in 2005 and held 238 statements (Razumnikova, 2005); and by N.A. Almayev and L.D. Ostrovskaya in 2005 and held 140 statements (Almayev and Ostrovskaya, 2005).

\section{The procedure of the implementation}

Football Basics Program included physical games and activities to make training more emotional and interesting for children. Various aspects of education are required for the harmonious development of an individual; for this reason attending arts and cultural events was arranged for orphan children to promote their spiritual and moral development (Thwala, 2013). It included attending Drama Theatre performances, master-classes and Personal Growth Trainings, arranging business games aimed at developing independence, logical thinking and the ability to solve non-standard challenges (PEPFAR, 2012). These activities ensure children's readiness for various life situations and development of their skills of adapting to different conditions. Training sessions were held three times a week (Monday, Wednesday, and Friday). Workshops were arranged in the morning three times a week (Tuesday, Thursday and Saturday), and there was attending arts and cultural events in the afternoon.

\section{Data analysis techniques}

Methods of mathematical statistics were used for processing and interpreting the experimental results. Specialized PC software was used for calculating the arithmetic average, mean error, variation coefficient and standard deviation. Further mathematical processing involved comparing the differences of averages according to the Student's tcriterion $\left(t_{\text {criterion }}\right)$. If, $t_{\text {estimated }}>t_{\text {criterion }}$, then the difference is significant, valid and did not occur by chance; if $\mathrm{t}_{\text {estimated }}<\mathrm{t}_{\text {criterion}}$, then the difference is not significant and occurred by chance. Mathematical correlation value is expressed by its coefficient from " -1 " (maximum positive relationship) to "+1" (maximum negative relationship) in decimal fractions with two decimal places accuracy.

The correlation coefficient is measured according to the following values:

0.99-0.9 - very strong relationship; 0.89-0.7 - strong relationship; 0.69-0.5 - visible relationship; 0.49-0.3 - moderate relationship; 0.29-0.1 - weak relationship; 0.09-0 - no relationship.

\section{FINDINGS}

Table 1 shows the results of the paper test on character traits and temperament of psychological features of orphans. 
Table 1

Results of Paper Test on Character Traits and Temperament of Psychological Features of Orphan Children (before the experiment)

\begin{tabular}{lrrrrrrrrrrr}
\hline \multicolumn{1}{c}{ Child number } & 1 & 2 & 3 & 4 & 5 & 6 & 7 & 8 & 9 & 10 \\
\hline $\begin{array}{l}\text { Results of paper test on character } \\
\text { traits and temperament (points) }\end{array}$ & 5 & 3 & 5 & 2 & 2 & 3 & 5 & 5 & 3 & 3 \\
\hline \multicolumn{7}{c}{ Control group } \\
\hline $\begin{array}{l}\text { Results of paper test on character } \\
\text { traits and temperament (points) }\end{array}$ & 3 & 5 & 3 & 2 & 3 & 5 & 3 & 3 & 3 & 3 \\
\hline
\end{tabular}

Note. 5 points $-5-6$ positive answers; 3 points -9 positive answers; 2 points -10 positive answers.

The obtained values allow to calculate the mean value $\left(\mathrm{X}_{\mathrm{m}}\right)$, standard deviation from the mean $\left(\sigma_{\mathrm{x}}\right)$, the ratio of the standard deviation to the arithmetic mean of the sample $(\mathrm{V} \%)$ and standard deviation of distribution $\left(\mathrm{S}_{\mathrm{x}}\right)$ (Table 2$)$.

Table 2

Indicators of Paper Test on Character Traits and Temperament of Psychological Features of Orphan Children (before the experiment)

\begin{tabular}{lll}
\hline Indicator & Experimental group & Control group \\
\hline$X_{\mathrm{m}}$ the mean value of the indicator & 4 & 3 \\
\hline$\sigma_{\mathrm{x}}$ standard deviation from the mean & 1.26 & 0.95 \\
\hline $\begin{array}{l}\mathrm{V} \% \text { the ratio of the standard deviation to the } \\
\text { arithmetic mean of the sample }\end{array}$ & 31.6 & 31.6 \\
\hline $\mathrm{S}_{\mathrm{x}}$ standard deviation of distribution $\mathrm{x}$ & 0.4 & 0.3 \\
\hline
\end{tabular}

Research results show that the subjects in experimental and control groups have psychological problems, which is proved by the test. Points from 3 to 5 demonstrate the signs of nervousness and some psychopathic deviations in the child's character; those are considered prominent features. As we see, the total score of the experimental group is 4 , while the total of the control group is 3 . Tables 1 and 2 demonstrate the results of psychological questioning of both groups before the teaching and educational process at the beginning of the school year. It should be mentioned that almost all subjects gave similar answers to the same questions.

Learning is not leading but the main activity of students. Studying various subjects, whether liberal arts or natural sciences, has an important beneficial influence on the development of thinking and intellect, thus good as well as poor academic performance is reflected in psychological processes. Researchers therefore considered it reasonable to check the academic performance of children. Table 3 shows results of the academic performance of orphans at the beginning of the school year, before football training, workshops, and attending arts and cultural events. 
Table 3

Results of the Academic Performance of Orphan Children (before the experiment)

\begin{tabular}{|c|c|c|c|c|c|c|c|c|c|c|}
\hline Child number & 1 & 2 & 3 & 4 & 5 & 6 & 7 & 8 & 9 & 10 \\
\hline \multicolumn{11}{|l|}{ Experimental group } \\
\hline $\begin{array}{l}\text { Students' academic } \\
\text { performance average (points) }\end{array}$ & 3 & 2.5 & 2.5 & 3 & 2.5 & 3 & 3 & 2.5 & 3 & 2.5 \\
\hline \multicolumn{11}{|l|}{ Control group } \\
\hline $\begin{array}{l}\text { Students' academic } \\
\text { performance average (points) }\end{array}$ & 3 & 3 & 2.5 & 3 & 3 & 3 & 3 & 3 & 2.5 & 2.5 \\
\hline
\end{tabular}

The obtained values allow to calculate the mean value $\left(\mathrm{X}_{\mathrm{m}}\right)$, standard deviation from the mean $\left(\sigma_{\mathrm{x}}\right)$, the ratio of the standard deviation to the arithmetic mean of the sample $(\mathrm{V} \%)$ and standard deviation of distribution $\left(\mathrm{S}_{\mathrm{x}}\right)$ (Table 4$)$.

Table 4

Academic Performance Indicators of Orphan Children (before the experiment)

\begin{tabular}{lll}
\hline Indicator & Experimental group & Control group \\
\hline $\mathrm{X}_{\mathrm{m}}$ the mean value of the indicator & 2.75 & 2.75 \\
\hline$\sigma_{\mathrm{x}}$ standard deviation from the mean & 0.26 & 0.24 \\
\hline $\begin{array}{l}\text { V\% the ratio of the standard deviation to the } \\
\text { arithmetic mean of the sample }\end{array}$ & 9.6 & 8.8 \\
\hline $\mathrm{S}_{\mathrm{x}}$ standard deviation of distribution $\mathrm{x}$ & 0.08 & 0.08 \\
\hline
\end{tabular}

To improve the physical education process orphan children were engaged in various physical games and activities close to football in their structure. Physical games and activities are a suitable type of physical exercises characterized by attractiveness, availability, deep and diverse impact. Exercises are an important component of training. They should be quick and interesting so that children look forward to participating in them. Nevertheless, it is impossible to use only active games and physical exercises because sportsmen might exhaust themselves. The special value of physical games and activities is that they have a simultaneous influence on the motor skills and mental sphere of children. The following set of physical games and activities aimed at developing strength and increasing flexibility was included into the educational and training process:

Table 5

Set of Physical Games and Activities Included into the Educational and Training Process

\begin{tabular}{|c|c|c|}
\hline Game type & Game name & Characteristics and influence on the harmonious development \\
\hline $\begin{array}{l}\text { 1. Games to } \\
\text { develop the } \\
\text { skills of } \\
\text { running, } \\
\text { passing, } \\
\text { catching and } \\
\text { dribbling the } \\
\text { ball. }\end{array}$ & $\begin{array}{l}\text { "Calling numbers", "Listen to the } \\
\text { signal", "Pass and sit down!", " } 25 \\
\text { passes", "Pass and run", "Meeting } \\
\text { halfway with two balls", "Dribbler } \\
\text { race", "Touch and run with the ball", } \\
\text { "Keep the ball", "Riders", "Fighting } \\
\text { for the ball", "Catcher and } \\
\text { interceptor", "Defend your friend" } \\
\text { etc. }\end{array}$ & $\begin{array}{l}\text { Games with a ball are a kind of gymnastics. Dribbling the ball children } \\
\text { practice walking, running and jumping. Exercises are performed in a } \\
\text { constantly changing environment, which promotes independent selection } \\
\text { of movements in the game. Children do not possess the precision of } \\
\text { movements, for this reason dribbling the ball facilitates the development } \\
\text { of this skill. Exercises and games with a ball develop major and minor } \\
\text { muscles of the hand, increase the mobility in the joints and, generally, } \\
\text { have a beneficial influence on the physical development and increase } \\
\text { endurance. }\end{array}$ \\
\hline 2. Games to & "Runners", "Run for the ball", "Hit & Quickness is successfully developed in many physical games and \\
\hline
\end{tabular}




\begin{tabular}{|c|c|c|}
\hline $\begin{array}{l}\text { develop } \\
\text { quickness. }\end{array}$ & $\begin{array}{l}\text { the town", "Catch the stick", " } \\
\text { Touch and run ", "Circular hunting", } \\
\text { "Day and night", "Four balls" etc. }\end{array}$ & $\begin{array}{l}\text { activities involving response to the signal, number of movements per } \\
\text { time unit, and the speed of body movement. A relay race is a good } \\
\text { example because exercises are performed at a quick pace. }\end{array}$ \\
\hline $\begin{array}{l}\text { 3. Games to } \\
\text { develop } \\
\text { strength. }\end{array}$ & $\begin{array}{l}\text { "Pulling in pairs", "Moving ring", } \\
\text { "Riders' fighting", "Cockfighting", } \\
\text { "Horserace", "Pushing out", "Hares } \\
\text { and walruses", "Car race", } \\
\text { "Crossing", "Who is stronger?" etc. }\end{array}$ & $\begin{array}{l}\text { In this type of games sportsmen have to either overcome their own } \\
\text { weight or the opponent's resistance. Sometimes such games include } \\
\text { activities with weights, which indicate a change in the strength-training } \\
\text { process (relay races with push-ups and pull-ups or flying balls). Due to } \\
\text { the emotional coloring of these games participant make efforts to achieve } \\
\text { individual and team victory. }\end{array}$ \\
\hline $\begin{array}{l}\text { 4. Games to } \\
\text { develop } \\
\text { general } \\
\text { endurance. }\end{array}$ & $\begin{array}{l}\text { "Catch me if you can", "Circle after } \\
\text { circle", "Catch the frog", "Jumping } \\
\text { rod", "Touch and run with the } \\
\text { skipping rope", "Train relay" etc. }\end{array}$ & $\begin{array}{l}\text { Endurance is manifested in dynamic activities with alternating periods of } \\
\text { tension and relaxation in muscles. These exercises, especially cyclic } \\
\text { ones, can cause fatigue and a decrease in endurance. For this reason } \\
\text { these exercises should be practiced in the second half of the class. }\end{array}$ \\
\hline $\begin{array}{l}\text { 5. Games to } \\
\text { develop } \\
\text { agility. }\end{array}$ & $\begin{array}{l}\text { "Catching in pairs", "Rolling", } \\
\text { "Quick hands", "Passing the ball on } \\
\text { the move", "With both hands", } \\
\text { "Penguin running", "Alone and } \\
\text { together" etc. }\end{array}$ & $\begin{array}{l}\text { Agility is the ability to efficiently change the body's position, learn new } \\
\text { movements and easily adjust the body movements in a changing } \\
\text { situation. Attention is paid to the time necessary for mastering new } \\
\text { movements and the level achieved after physical games and activities. } \\
\text { In these games children have to quickly switch from one movement to } \\
\text { another and solve tasks taking into account the movements of their game } \\
\text { partners. }\end{array}$ \\
\hline $\begin{array}{l}\text { 6. Games to } \\
\text { increase } \\
\text { flexibility. }\end{array}$ & $\begin{array}{l}\text { "Stick behind the back", "Ball race", } \\
\text { "Lobster running", "Bridge and cat", } \\
\text { "Bench over your head" etc. }\end{array}$ & $\begin{array}{l}\text { Flexibility involves crossing the joints to induce a bending movement or } \\
\text { motion. Relay races can be used to increase flexibility. Games that } \\
\text { influence the complex interaction of joints, ligaments and muscles may } \\
\text { also be introduced. In these games the range of motion is increased and it } \\
\text { provides additional stretching of muscles and ligaments. }\end{array}$ \\
\hline
\end{tabular}

During the experiment that lasted 7 months (October, 2017 - April, 2018) orphan children attended training, actively participated in extracurricular sport, arts and cultural activities.

Children underwent three Personal Growth Trainings (October, January, April): Introductory Personal Development Program, Steps to Positive Thinking, Success Training, within which workshops, business-games, individual counseling and motivational speaking were organized. In a lively and relaxed atmosphere that kept the children involved and interested, they practiced focusing on positive thoughts, feelings, and ideas; making choices and dealing with the consequences of what they have chosen; making better decisions, and taking purposeful actions. Once a month the children were taken to the Russian Drama Theatre (Naberezhnye Chelny, Republic of Tatarstan), the Tatar Drama Theatre and the Young Spectator's Theatre (Nizhnekamsk, Republic of Tatarstan) to see the performances of Russian and Tatar classics. Theatre-going within the experiment was aimed at stimulating the children to read and discuss motivational, inspirational and educational literature. Attending concerts of classical music was organized on a regular basis: Lerman Chamber Orchestra (Naberezhnye Chelny, Republic of Tatarstan) in the Organ Hall and the Orchestra of Folk Instruments (Elabuga, Republic of Tatarstan). All arts and cultural activities, arranged within the experiment, were aimed at promoting the children's spiritual, moral and mental development, showing them a full, emotionally rich life in which they can satisfy their natural, social and spiritual needs and prepare themselves for adult independent life.

\section{Analysis of experimental results}

At the end of the experiment the authors conducted the questionnaire including the same questions which were asked at the beginning of the experiment and checked the academic progress of children in the control and experimental groups. Table 6 shows the test results of orphan children at the end of the experiment. 
Table 6

Results of Paper Test on Character Traits and Temperament of Psychological Features of Orphan Children (after the experiment)

\begin{tabular}{|c|c|c|c|c|c|c|c|c|c|c|}
\hline Child number & 1 & 2 & 3 & 4 & 5 & 6 & 7 & 8 & 9 & 10 \\
\hline \multicolumn{11}{|l|}{ Experimental group } \\
\hline $\begin{array}{l}\text { Results of paper test on character } \\
\text { traits and temperament (points) }\end{array}$ & 8 & 6 & 6 & 5 & 5 & 5 & 8 & 8 & 6 & 6 \\
\hline \multicolumn{11}{|l|}{ Control group } \\
\hline $\begin{array}{l}\text { Results of paper test on character } \\
\text { traits and temperament (points)) }\end{array}$ & 6 & 5 & 5 & 3 & 3 & 5 & 6 & 3 & 5 & 3 \\
\hline \multicolumn{11}{|c|}{$\begin{array}{l}\text { Note: } 8 \text { points }-1-2 \text { positive answers; } 6 \text { points }-4 \text { positive answers; } 5 \text { points }-5-6 \text { - } \\
\text { positive answers; } 3 \text { points }-9 \text { positive answers. }\end{array}$} \\
\hline \multicolumn{11}{|c|}{$\begin{array}{l}\text { The obtained values allow to calculate the mean value }\left(\mathrm{X}_{\mathrm{m}}\right) \text {, standard deviation from the } \\
\text { mean }\left(\sigma_{\mathrm{x}}\right) \text {, the ratio of the standard deviation to the arithmetic mean of the sample (V\%) } \\
\left.\text { and standard deviation of distribution }\left(\mathrm{S}_{\mathrm{x}}\right) \text { (Table } 7\right) \text {. }\end{array}$} \\
\hline \multicolumn{11}{|c|}{$\begin{array}{l}\text { Table } 7 \\
\text { Indicators of Paper Test on Character Traits and Temperament of Psychological } \\
\text { Features of Orphan Children (after the experiment) }\end{array}$} \\
\hline \multicolumn{4}{|l|}{ Indicator } & \multicolumn{4}{|c|}{ Experimental group } & \multicolumn{3}{|c|}{ Control group } \\
\hline \multicolumn{3}{|l|}{$X_{m}$ the mean value of the indicator } & & & \multicolumn{3}{|l|}{4.5} \\
\hline \multicolumn{4}{|l|}{$\sigma_{\mathrm{x}}$ standard deviation from the mean } & \multicolumn{4}{|l|}{1.25} & \multicolumn{3}{|c|}{1.3} \\
\hline \multicolumn{3}{|c|}{$\begin{array}{l}\text { V\% the ratio of the standard deviation to the arithmetic } \\
\text { mean of the sample }\end{array}$} & & \multicolumn{4}{|l|}{17.9} & \multicolumn{3}{|c|}{39.9} \\
\hline \multicolumn{4}{|l|}{$\mathrm{S}_{\mathrm{x}}$ standard deviation of distribution $\mathrm{x}$} & \multicolumn{4}{|l|}{0.4} & \multicolumn{3}{|l|}{0.4} \\
\hline
\end{tabular}

At the end of the school year after the experiment the children's academic performance evaluation was made in the control and experimental groups (Table 8).

Table 8

Results of the Academic Performance of Orphan Children (after the experiment)

\begin{tabular}{lcccccccccc}
\hline Child number & 1 & 2 & 3 & 4 & 5 & 6 & 7 & 8 & 9 & 10 \\
\hline Experimental group & & & & & & & & & & \\
\hline $\begin{array}{l}\text { Students' academic performance } \\
\text { average (points) }\end{array}$ & 4 & 3.5 & 3 & 3.5 & 3 & 3 & 4 & 2.5 & 3 & 3 \\
\hline $\begin{array}{l}\text { Control group } \\
\begin{array}{l}\text { Students' academic performance } \\
\text { average (points) }\end{array}\end{array}$ & 3 & 3.5 & 3 & 3 & 3 & 2.5 & 3 & 3 & 3 & 2.5 \\
\hline
\end{tabular}

The obtained values allow to calculate the mean value $\left(\mathrm{X}_{\mathrm{m}}\right)$, standard deviation from the mean $\left(\sigma_{\mathrm{x}}\right)$, the ratio of the standard deviation to the arithmetic mean of the sample $(\mathrm{V} \%)$ and standard deviation of distribution $\left(S_{\mathrm{x}}\right)$ (Table 9$)$.

Table 9

Academic Performance Indicators of Orphan Children (after the experiment)

\begin{tabular}{lll}
\hline Indicator & Experimental group & Control group \\
\hline $\mathrm{X}_{\mathrm{m}}$ the mean value of the indicator & 3.5 & 3 \\
\hline$\sigma_{\mathrm{X}}$ standard deviation from the mean & 0.5 & 0.2 \\
\hline $\begin{array}{l}\text { V\% the ratio of the standard deviation to the arithmetic } \\
\text { mean of the sample }\end{array}$ & 13.9 & 7.1 \\
\hline $\mathrm{S}_{\mathrm{x}}$ standard deviation of distribution $\mathrm{x}$ & 0.2 & 0.1 \\
\hline
\end{tabular}


Visual representation of the obtained results is given in the diagram which shows the questionnaire results of both groups before and after the experiment (Figure 2, 3).

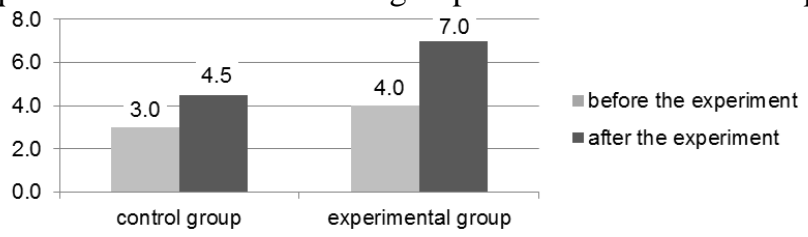

Figure 2

Results of Paper Test on Character Traits and Temperament of Psychological Features of Orphan Children (before and after the experiment)

As can be seen from Figure 2, at the beginning of the experiment the mean value of indicators of paper test on character traits and temperament in the control group is 3 points, to the end of the experiment it increased to 4.5 points. The results of the experimental group are 4 points and 7 points correspondingly. Points from 3 to 5 demonstrate the fact that the deviation features in the mental development are prominent. Thus, at the beginning of the experiment both groups demonstrate clear signs of nervousness and some psychopathic deviations in the child's character ( $\mathrm{t}_{\text {estimated }}<$ $t_{\text {criterion }}(2.000<2.101)$ at $\alpha=0.005$ level of confidence). At the end of the experiment we see that the control group indicators remain without changes, while the experimental group shows an increase to 7 points, which characterizes the mean value of the degree of manifestation ( $\mathrm{t}_{\text {estimated }}>\mathrm{t}_{\text {criterion }}(4.443>2.101)$ at $\alpha=0.005$ level of confidence).

Figure 3 shows academic performance indicators of orphan children before and after the experiment.

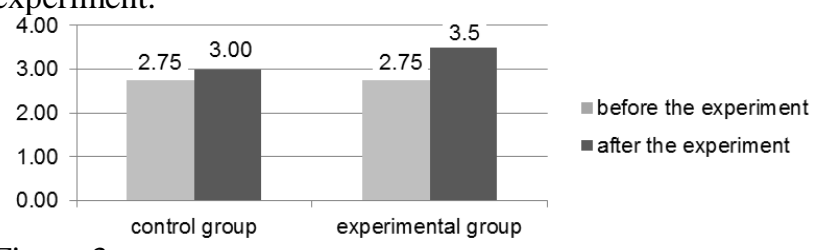

Figure 3

Academic Performance Indicators of Orphan Children (before and after the experiment)

As can be seen from Figure 3, at the beginning of the teaching and educational process the academic performance indicator of both groups was 2.75 points on a five-point scale ( $\mathrm{t}_{\text {estimated }}>\mathrm{t}_{\text {criterion }}(0<2.101)$ at $\alpha=0.005$ level of confidence). At the end of the teaching and educational process the results were as follows: an increase to 3 points in the control group, an increase to 3.5 points in the experimental group ( $t_{\text {estimated }}>t_{\text {criterion }}(2.928>$ 2.101) at $\alpha=0.005$ level of confidence). The obtained data show that children from the experimental group demonstrate better scores on the paper test on character traits and temperament and better academic performance. The authors consider it to be the result of the specific set of educational and training activities and organizing arts and cultural events for their harmonious development. 


\section{DISCUSSION AND IMPLEMENTATIONS}

The general physical and psychological development of children left without parental care differs from the development of their peers raised in families (Penkin, 2003). The present research was intended to study the effect of seven months of football basics program, personal growth trainings and attending arts and cultural events on a regular basis by the experimental group of orphan adolescents as compared to the control group. This issue is of importance for two reasons. Firstly, it shows the interdependence of physical activity, promoted by football basics program, and psychological indicators of harmonious development of orphan children. Secondly, the integrated program of physical activities and arts and cultural events promotes success in learning and improves social interaction of orphan children and children left without parental care.

Studies demonstrate that material support alone is not sufficient for orphan children; they are particularly sensitive to the possible presence of a depressive disorder, feelings of hopelessness, and suicidal ideation (Atwine et al., 2005). Orphanages are often the only level of care available for children left without parental care, but such care may increase children's risk for psychological, emotional and developmental problems (Bettmann et al., 2015). The formation of psychological stability as an integral characteristic of the personality is of major importance especially for adolescence in which life adversities or difficulties are subjectively viewed as extreme and crisis (Matyash and Volodina, 2015). Many orphans show signs of emotional need and they lag behind in their academic work. According to the results of the previous study psychosocial support provided to orphan children over a period of eight months results in improvements in several areas, including schoolwork (Chitiyo et al., 2008).

Present study also demonstrates that orphan children should be involved in the teaching and educational process aimed at their harmonious development throughout the school year. This condition ensures the significant increase in the indicators of children's harmonious development (Nikitina et al., 2015). The effect of the realized integrated program provides evidence on improving orphan adolescents' indicators: they demonstrate better scores on the paper test on character traits and temperament (increase to 7 points in the experimental group) and better academic performance (an increase to 3 points in the control group, an increase to 3.5 points in the experimental group). The study proves that the special value of physical games and activities included into the program is that they have a simultaneous influence on the motor skills and mental sphere of children. Physical activities are also shown to be beneficial in improving physical fitness in children with intellectual and developmental disabilities; they develop the fitness capacities essential to participation in a wide variety of activities (Collins and Staples, 2017; Ridley et al., 2018). The positive effect of physical activities on cognitive and psychosocial health is revealed in studies of different age groups (Korczak et al., 2017; McNeill et al., 2018).

The effect of introducing football basics into Physical education of orphan children is comparable with the effect of the Yoga program, which provides evidence on improving cognitive functions in orphan adolescents. Recent studies have demonstrated yoga sessions were positively associated with improvement in mood and anxiety scales, and 
reduction in depressive symptoms (Purohit and Pradhan, 2017). Development of social and educational support in Russian orphanages will also contribute to their harmonious development. The social teacher's support is manifested in the emergence of new forms of work including family arrangements, the reunion with the blood relatives, guidance after leaving school; training adolescents for their independent adult life; individualization of social and pedagogical support, changing life style in the institution to family-oriented (Bobyleva, 2015). In summary, the present findings provide new evidence on the importance of physical games and activities in promoting harmonious development of orphan children and children left without parental care. The practical implications suggest that an integrated football basics and arts and cultural events program can lead to a significant increase in psychological indicators of character and temperament traits and academic performance.

\section{CONCLUSION}

The contents and methods of teaching acquire specific features in various kinds of sports depending on the targets that have been set. For instance, it is reasonable to engage orphan children in different physical games and activities close to football in their structure. It is physical games and activities that make a suitable type of physical exercises characterized by attractiveness, availability, deep and diverse impact. Research results demonstrate that psychological indicators of the subjects tend to improve. The control group showed a 1.0 point increase, the experimental group showed a 2.5 point increase in the test on character traits and temperament. Academic performance of children improved in both groups to the end of the school year: by 0.5 points in the control group, by 0.75 points in the experimental group. It was found that learning football basics in physical education and organizing arts and cultural events for orphan children play a significant role in their harmonious development. The results were obtained due to the specific set of teaching and educational activities, aimed at the harmonious development of orphan children.

\section{Practical Recommendations}

The analysis of the obtained research results allows the authors to make the following recommendations on increasing the efficiency of training. Thus, at the beginning of working with orphan children cooperative work should be organized to ensure the coordination of actions; the plan of activities should be agreed with the social teacher and the psychologist. To increase the efficiency of training it is necessary to introduce a set of exercises including a variety of physical games and activities; it awakens the interest in the training and brings positive emotions. The authors consider that for the successful work with orphan children it is recommended to be more polite, kind, but moderately strict, to enjoy their success, to create the atmosphere of mutual understanding, respect, and assistance. It is always important to believe that education can work wonders.

\section{ACKNOWLEDGEMENTS}

The work is performed according to the Russian Government Program of Competitive Growth of Kazan Federal University. 


\section{REFERENCES}

Alloway, T. P, \& Alloway, R. G. (2010). Investigating the predictive roles of working memory and IQ in academic attainment. J Exp Child Psychol, 106, 20-29.

Almayev, N. A, Ostrovskaya, L. D. (2005). Russian-language Adaptation of Temperament and Character Inventory by Cloninger. Psychological Journal, 26(6), 77 86.

Anyikwa, N., \& Obidike, N. (2012). Mothers' constructions of their roles in the literacy education of their children. Africa Development, 37(3), 57-67.

Asif, A. (2017). Self-Esteem and Depression among Orphan and Non-Orphan Children. Dubai UAE: MedCrave Group LLC.

Atwine, B., Cantor-Graae, E., Bajunirwe, F. (2005) Psychological distress among AIDS orphans in rural Uganda. Social Science and Medicine, 61(3), 555-564. doi.org/10.1016/j.socscimed.2004.12.018

Better Care Network Secretariat (2009). Global Facts about Orphanages. New York, NY: Better Care Network.

Bettmann, J., Mortensen, J., Akuoo, K. (2015). Orphanage caregivers' perceptions of children's emotional needs. Children and Youth Services Review, 49, 71-79. doi.org/10.1016/j.childyouth.2015.01.003

Bobyleva, I. (2015). Development of Social and Educational Support in Russian Institutions for Orphans. Procedia-Social and Behavioral Sciences, 214, 535-543.

Borella, E, Carretti, B, Pelegrina, S. (2010). The specific role of inhibition in reading comprehension in good and poor comprehenders. J Learn Disabil.,43, 541-552.

Braginskiy, V. (2005). Life without Warmth and Bright Impressions: Why Can't Orphanage Inmates Integrate into Society? Children's Health, 10, 36-39.

Campbell, P., Handa, S., Moroni, M., Odongo, S., \& Palermo, T. (2010). Assessing the "orphan effect" in determining development outcomes for children in 11 eastern and southern african countries. Vulnerable Children and Youth Studies, 5(1), 12-32. doi:10.1080/17450120903193907

Children homes' statistics (2017). Vavilon. Retrieved April 30, 2018, from http://vawilon.ru/statistika-detskih-domov/\#skolko-detej-sirot-v-rossii

Chiroma, N. H. (2016). Providing mentoring for orphans and vulnerable children in internally displaced person camps: The case of northern Nigeria. HTS Teologiese Studies / Theological Studies, 72(1) doi:10.4102/hts.v72i1.3544

Chitiyo, M., Changara, D., Chitiyo, G. (2008). Providing psychosocial support to special needs children: A case of orphans and vulnerable children in Zimbabwe. International Journal of Educational Development, 28(4), 384-392. doi.org/10.1016/j.ijedudev.2007.05.009 
Cloninger, R. (1994). The temperament and character inventory (TCI): A guide to its development and use. St. Louis, MO: Center for Psychobiology of Personality, Washington University.

Collins, K., Staples, K. (2017) The role of Physical activity in improving physical fitness in children with intellectual and developmental disabilities. Research in Developmental Disabilities, 69, 49-60.

Crockenberg, S. C., Rutter, M., Bakermans-Kranenburg, M. J., van IJzendoorn, M. H., Juffer, F. (2008). The effects of early socialemotional and relationship experience on the development of young orphanage children. St., Petersburg, USA: The St., Petersburg USA Orphanage Research Team. Monographs of the Society for Research in Child Development, 73(3).

Dubrovina, I. V., Minkova, E. A., Bardyshevskaya, M. K. (1995). About the Development of Children Left Without Parental Care: Essays. Moscow: "SIMS", Limited Liability Partnership (LLP).

Erango, M. A., \& Ayka, Z. A. (2015). Psychosocial support and parents' social life determine the self-esteem of orphan children. Risk Management and Healthcare Policy, 8, 169-173. doi:10.2147/RMHP.S89473

Escueta, M., Whetten, K., Ostermann, J., \& O'Donnell, K. (2014). Adverse childhood experiences, psychosocial well-being and cognitive development among orphans and abandoned children in five low income countries. BMC International Health and Human Rights, 14(1) doi:10.1186/1472-698X-14-6

Jeffery, C., Crossland, N., \& Valadez, J. J. (2015). Access to education for orphans and vulnerable children in uganda: A multi-district, cross-sectional study using lot quality assurance sampling from 2011 to 2013. PLoS ONE, doi:10.1371/journal.pone.0132905

Kayombo, E. J., Mbwambo, Z. H., \& Massila, M. (2005). Role of traditional healers in psychosocial support in caring for the orphans: A case of Dares Salaam city, Tanzania. Journal of Ethnobiology and Ethnomedicine, 1, doi:10.1186/1746-4269-1-3

Kiambi, E. G., Mugambi, M. M. (2017). Factors influencing performance of orphans and vulnerable children projects in Imenti North Sub county, Meru county, Kenya. International Academic Journal of Information Sciences and Project Management, 2(1), 179-196.

Korczak, J., Madigan, S., Colasanto, M., Szatmari, P., Chen, Y., Maguire, J., Parkin, P., Birken, C. S. (2017). The longitudinal association between temperament and physical activity in young children. Preventive Medicine, 111, 342-347.

Lingenfelter, W. V., Solheim, K., \& Lawrence, A. (2017). Improving secondary education for orphans and vulnerable children in malawi: One non-governmental organization's perspective. Child and Youth Services, 38(2), 142-158. doi:10.1080/0145935X.2017.1297201 
Lupu, E., Petrescu A.L. (2012). A study regarding teenagers' self-image and the importance of physical activities in its formation. Procedia-Social and Behavioral Sciences, 33, 870-874. doi.org/10.1016/j.sbspro.2012.01.246

Majanga, E., Mukonyi, P., Vundi, S. (2015). Socio-pedagogical challenges facing orphaned and vulnerable children in the aftermath of the 2007-2008 election violence in Nakuru County, Kenya. Journal of Education and Practice, 6(6), 155-160.

Makame, V., Ani, C., \& Grantham-McGregor, S. (2002). Psychological well-being of orphans in Dar el Salaam, Tanzania. Acta Paediatrica, International Journal of Paediatrics, 91(4), 459-465. doi:10.1080/080352502317371724

Matyash, N., Volodina, J. (2015). Psychological Stability of Orphans in Crisis Situations. Procedia - Social and Behavioral Sciences, 214, 1070-1076.

McNeill, J., Stewart, J. H., RuteSantos, A. V., Cliff, D. P. (2018). Physical activity and modified organized sport among preschool children: Associations with cognitive and psychosocial health. Mental Health and Physical Activity, 15, 45-52.

Naidu, V., Aguilera, J. F., de Beer, J., Netshipale, P., \& Harris, G. (2008). Cost and quality performance indicators for home community-based care services to orphans and vulnerable children. South African Journal of Economics, 76(SUPPL. 1), S28-S33. doi:10.1111/j.1813-6982.2008.00167.x

Nikitina, N. I., Romanova, E. Y., Igorevna, L. M., Tolstikova, S. N., \& Grebennikova, V. M. (2015). Socio-pedagogical support of child's upbringing in a tutorial family. Mediterranean Journal of Social Sciences, 6(3S3), 165-174. doi:10.5901/mjss.2015.v6n3s3p165

Nyberg, B. J., Yates, D. D., Lovich, R., Coulibaly-Traore, D., Sherr, L., Thurman, T. R., Sampson, A., Howard, B. (2012). Saving lives for a lifetime: Supporting orphans and vulnerable children impacted by HIV/AIDS. Journal of Acquired Immune Deficiency Syndromes, 60(SUPPL.3), S127-S135. doi:10.1097/QAI.0b013e31825da836

Penkin, V. N. (2003). The influence of being an orphan on the physical development of children. [Vliianie sirotstva na fizicheskoe razvitie detei.] Problemy Sotsialnoi Gigieny, Zdravookhraneniia i Istorii Meditsiny / NII Sotsialnoi Gigieny, Ėkonomiki i Upravleniia Zdravookhraneniem Im.N.A.Semashko RAMN ; AO "Assotsiatsiia 'Meditsinskaia Literatura'.", (5), 19-20.

Pillay, J. (2018). Early education of orphans and vulnerable children: A crucial aspect for social justice and african development. Koers, 83(1) doi:10.19108/KOERS.83.1.2335

Purohit, S. P., Pradhan, B. (2017). Effect of yoga program on executive functions of adolescents dwelling in an orphan home: A randomized controlled study. Journal of Traditional and Complementary Medicine, 7, 99-105.

Rayzikh, A. A., Maksimova, S. S., Ivanova, E. S., \& Alabuzhev, A. E. (2017). Organizational and educational conditions for schoolchildren's precompetitive training 
for all-russian physical education olympiad finals. Teoriya i Praktika Fizicheskoy Kultury, 2017(1)

Razumnikova, O. M. (2005). R. Cloninger's Character and Temperament Inventory. Siberian Journal of Psychology, 22, 150-152.

Ridley, K., Zabeen, S., Lunnay, B. K. (2018). Children's physical activity levels during organised sports practices. Journal of Science and Medicine in Sport, 21(9), 930-934.

Sabau, E., Niculescu, G., Gevat, C., Lupu, E. (2014). Identification of the Balance Capability - A Perceptual-motor Component-in Teenagers. Procedia-Social and Behavioral Sciences, 127, 260-264. doi.org/10.1016/j.sbspro.2014.03.252

The U.S. President's Emergency Plan for AIDS Relief (PEPFAR) (2012). Guidance for Orphans and Vulnerable Children Programming. Washington, DC: PEPFAR. Retrieved from https://www.pepfar.gov/documents/organization/195702.pdf

Thwala, S. K. (2013). The role of culture in psychosocial development of orphans and vulnerable children. International Journal of Adolescence and Youth, 18(2), 105-121. doi:10.1080/02673843.2012.665169

UNICEF (2017). Orphans. Retrieved April 30, 2018, from https://www.unicef.org/media/media_45279.html

Worldwide Children's Statistics (2018). SOS Children's Villages - USA, Inc. Retrieved April 30, 2018, from https://www.sos-usa.org/our-impact/childrens-statistics

Yenikolopov, S. N., Yefremov, A. G. (2001). Approbation of Cloninger's Biosocial Methodology "Structure of Character and Temperament". Materials of the First International Conference Dedicated to the Memory of B.V. Zeigarnik. Moscow: MGU, 104-105.

Zhou, G. (2012). Understanding the Psychosocial Well-being of Orphans and Vulnerable Children (OVC): The Intersection of Research and Policy (Undergraduate Honors Thesis, Sanford Institute of Public Policy Studies, Duke University - Durham, NC). $\quad$ Retrieved from https://dukespace.lib.duke.edu/dspace/bitstream/handle/10161/5386/Grace\%20Zhou\%2 0FINAL.pdf;sequence $=1$ 